\title{
Antecedents to Customer Engagement: Moderating Role of Media Richness of Brand Pages
}

\author{
Aditi Gosain, Mukta Srivastava*, Deepanvita Gupta \\ School of Business Management, NMIMS, Mumbai, India \\ Email: aditi.a.gosain@gmail.com, ^muktassrivastava78@gmail.com, hdeepanvita@gmail.com
}

How to cite this paper: Gosain, A., Srivastava, M. and Gupta, D. (2019) Antecedents to Customer Engagement: Moderating Role of Media Richness of Brand Pages. Theoretical Economics Letters, 9, 2550-2565. https://doi.org/10.4236/tel.2019.97161

Received: August 26, 2019

Accepted: October 11, 2019

Published: October 14, 2019

Copyright (อ 2019 by author(s) and Scientific Research Publishing Inc. This work is licensed under the Creative Commons Attribution International License (CC BY 4.0).

http://creativecommons.org/licenses/by/4.0/

\section{(c) (i) Open Access}

\begin{abstract}
A key contributor to a brand's strength is how well its customers are engaged with the brand. With marketers spending huge amounts of money on social media presence of their brands, it becomes vital to assess how well this social media presence in the form of brand pages is able to generate customer engagement. This study explores the characteristics of online brand pages and examines how they impact customer engagement with the brands. We also examine the moderating role of brand pages' media richness in relationship with the characteristics of the brand page and customer engagement. The conceptual model proposed is evaluated using data from 479 survey responses towards 23 brand pages. This study contributes to the literature on customer engagement by proposing a decomposition of its dimensions and studying it in a system of conceptual relationships with its antecedents.
\end{abstract}

\section{Keywords}

Brand Categories, Social Media Platforms, Customer Engagement, Brand Pages

\section{Introduction}

A brand page is a profile on a social networking site and enables companies to generate added value for their brands and customers. Companies are realising the potential of social network on the internet and leveraging theses for business opportunities. The usage of social media (e.g., Facebook, LinkedIn, Youtube, Twitter) has grown significantly amongst customers. According to Global Digital Report 2019, 3.484 bn people in the world use social media and there are about 3.256 bn using social media on mobile phones [1]. Corporate correspon- 
dence conveyed through social networks is an exponentially developing tool of marketing with consistently expanding number of users. Given the expansion of various types of social media, there is much debate on the level of control and oversight that organizations need to exert on this communication tool especially when corresponding with customers. A large number of organizations have faith in the high potential of these networks as millions of prospects spend hours on this communication tool.

This seems to be reflected in the growing trend among corporate houses to set up social media command centres using digital outreach agencies. Companies like Taj Hotels, Airtel, Hindustan Unilever Limited, Nestle, Sula Vineyards, Marriott, and L'Oreal are amongst those that have invested in such centres with an objective of engaging with consumers online [2].

In India, the adoption of social media over the last few years has been rapid. This has been possible because of the high mobile (particularly smartphone) penetration coupled with low telecom tariffs. A high proportion (92.6\%) of total internet subscribers are mobile internet subscribers. Also, by 2030, there will be 1.1 billion internet users in India and $78.8 \%$ of total population would be online [3]. The large mobile subscriber base, high data demand and deep smartphone penetration have driven investments in social media, mobile internet and m-commerce.

With marketers spending huge amounts of money on social media presence of their brands, it becomes vital to assess how well this social media presence in the form of brand pages is able to generate customer engagement. Though there has been enough research done in the area of customer engagement [4] [5] [6], however, not much empirical research work has been done on customer engagement in the context of online brand pages.

The purpose of the present study, therefore, is to explore the characteristics of online brand pages and examine how they impact customer engagement with the brands. The rest of the article has been structured as follows: literature review followed by conceptual framework and hypothesis, methodology, results, discussion and conclusion.

\section{Literature Review}

\section{Customer Engagement}

Engagement, as a concept, has received wide attention across disciplines like information systems, business management, marketing and other areas of social sciences [7] [8] [9] [10]. Some of the aspects of customer engagement explored specifically in marketing-related research are with regard to brands [11], organisations and product management [12] and brand communities [13]. Customer engagement has a positive influence on realization of sales and marketing objectives [14] [15]. However, the concept of customer engagement suffers from a lack of consensus on its meaning, dimensions and operationalisation. 
A number of studies have explored customer engagement in the context of communities as a psychological state [9] [13] [14] [16] [17] [18]. Patterson et al. [12], Bowden [7], and Brodie, Hollebeek, Juric, \& Ilic, [6] have studied it in the context of customer services. Customer engagement has also been studied in the context of brands and customer relations [15] [19]. Not only has the context differed across studies but also the conceptualizations and the possible antecedents of customer engagement. It may thus be safely concluded that the concept of customer engagement needs more refinement in its definition and its interpretation.

It is worth noting that as a concept, customer engagement is complex and multidimensional. Most of the researchers have considered it as a multi-dimensional concept in the rainbow spanning the cognitive, emotional, behavioural and even social aspect [7] [16] [20] [21] [22] [23]. For instance, as defined by Hollebeek [21], "customer (brand) engagement is the level of customer's cognitive, emotional and behavioural investment in specific brand interactions". Also, Brodie et al. [5] defined it as "a psychological state that occurs by virtue of interactive, co-creative experiences with a focal agent/object (e.g. a brand)."

While there has been a lot of work in the area of customer engagement, most of the recent work has been descriptive [6] [8] [9] [24]. We do find some research work of empirical and qualitative nature, where researchers have explored how brands are affected by customer engagement [15] [19] and the effect of brand communities [20] [25].

Chan et al. [17] while studying online social media explored the dimensions of customer engagement. They proposed vigour, absorption, and dedication as key aspects or dimensions of customer psychological engagement. This has some parallels with Patterson et al. [12], who posited that psychological engagement of a customer is based on the extent of vigour, dedication, absorption and interaction. Newman and Harrison [26] also suggest that engagement is a multidimensional construct.

The present study adopts the dimensions of customer psychological engagement from Patterson's [12] work in the context of a brand. This provides us the framework of three dimensions of customer engagement. The first of these is vigour which denotes the level of energy of the customer and also his willingness to spend time and effort. The second is absorption, which signifies the extent of a customer being concentrated, happy, and engrossed. The third dimension is dedication, which relates to the degree to which the customer perceives a sense of significance, zeal, motivation, egotism, and challenge towards brands.

\section{Conceptual Model and Hypotheses Development}

The present study recognized three major types of antecedents of customer engagement with reference to brand pages. As Pervan Doorn et al. [24], customer engagement is influenced by personality characteristics of customers, company 
initiatives, and the context. The present study uses self-expressive behaviour as representing consumer characteristics. Company initiatives denote the efforts made by a firm to improve customer engagement which may use media richness as a moderator and information quality as a predictor. The present study focuses on customer engagement at the level of a consumer. Also, since social interaction is often found on brand pages, this study utilizes social interaction to capture the contextual influence.

\subsection{Antecedents of Customer Engagement}

\section{Informational quality}

The brand page is principally presented as an application of multimedia technology. In order to achieve its purpose, it has to provide some functional value for visitors. Brand pages are quite different in how they present information which may be a function of the product, service, brand philosophy or several other factors. However, without attempting to understand the underlying philosophy or objectives of the brand, we attempt to look at a variable denoting the subjective assessment of the brand page. $\mathrm{Wu}$ [27] attempted to codify the information available on a brand page using several parameters. This includes the accuracy of the information, the validity of data, the objectivity amongst others. This is also referred to formally as an informational quality which can be conceptualized as the perceived overall value and excellence of information posted on the brand page. A brand page high on this overall measure will provide a great deal of value for visitors [28]. It can thus be posited that the level of customer engagement will increase with higher levels of information quality. Therefore, we propose:

H1: Information quality of the brand page positively influences customer engagement with the brand page.

\subsection{Social Interaction}

Social networking sites were initially mooted as information sharing platforms and have slowly morphed into platforms for social interaction [29]. Interaction on brand pages takes the form of exchanging opinions, reviews and experiences which are related to the brands in question [25]. The provision for customer interaction has become so imperative that today most brand pages elicit opinions from visitors and encourage interaction. This was in line with the argument made by Liang, Ho, Li, \& Turban [30] support of users' social interaction is important for brand pages since this, in turn, increases the level of confidence in the brand. An additional advantage of such encouragement is the strengthening of visitors' social identities with the brands. Therefore, we hypothesize that increasing interactivity between customers should increase social identity and ultimately customer engagement.

H2: The quality of social interaction in the brand page positively influences the customer engagement with the brand page. 


\subsection{Self-Expressive Behaviour}

The Self, as an abstract concept, is partially created by an individual dynamically through consumption [31] [32]. Thompson [33] describes the self as "a symbolic project, which the individual must actively construct out of available symbolic materials, materials which the individual weaves into a coherent account of who he or she is, a narrative of self-identity". Self-concept has been defined as "the relatively stable schemata of oneself that are generalized to the extent that they refer to an individual's view of him- or herself across different situations" ([34], p. 95). Social media are popular platforms for self-expression, communication and self-promotion. The emergence of what Castells [35] has termed "mass self-communication" as a global system of networked interaction-a system within which platforms like Facebook, LinkedIn, Google Plus ${ }^{1}$ and Twitter offer crucial tools to galvanize the expression of online identity.

The personal image or the product user image is "the image formed of a generalized user of the product through advertising" [36]. Brands are consumed not only for their utilitarian purpose but also for the symbolic associations of the brands projected in their image [37]. Prior research suggests that customer's consumption is directly related to their perception of similarity of the product-user image to their own self-image [36] [38] [39].

The relationship of a person with a brand in terms of the strength and depth has been a subject of study for quite a while now [36]. Several researchers have reported how consumers tend to feel that possessions are an extension of themselves and help define their sense of self [40] [41]. While describing brands, consumers also go so far as to project their own personality characteristics onto them [42].

Goffman [43] argued that individuals tend to sculpt their personalities using the mode of intentional presentation. Sometimes, several of these displays are not intentional but yet become a part of self-expression. In the context of SNSs, while conscious self-promotion is the overt objective of a user, there is also unconscious self-expression. These are designed by the owners of these platforms using sophisticated interface technologies. Attachment to a brand is thus likely to increase in cases where customers project their self on brands. Therefore, we hypothesize that:

H3: Self-expressive behaviour of the respondent has a positive impact on customer engagement with the brand page.

\subsection{Moderating Role of Media Richness}

Brand pages on the SNSs are typically very heterogenous in their appearance and content. This is usually a reflection of the brand imagery and the objectives of the brand for the page. Brand pages also vary by the type of media used on the page. This can be differentially measured using the variable of media richness. The media richness theory [44] defines contextual cues in a communication me${ }^{1}$ Data for this study was collected well before March 2019 when Google Plus was withdrawn for consumers. 
dium as its "richness". "Richness" in the form of visual cues generally tend to increase the effectiveness of the medium. Daft and Lengel [44] have attempted to study media richness and find that it is a function of several characteristics of the medium. This could the variety of language, the number of cues and the capacity for prompt feedback amongst others. SNS pages, as used by brands, offer different media types which, in turn, affects media richness of these pages. Brand pages and posts therein can be bare in the form of text or could include audio-visual media. Hence, one could conceptualise a continuum of message richness for these posts on brand pages. At one extreme one could have text-only posts which are leaner media-types and at the other extreme one could have posts containing embedded photos, videos, or URLs. The effectiveness of the medium will also increase with this gradation. Hence, we anticipate that the use of richer media, such as photos, videos, or URLs, is associated with higher customer engagement. Therefore, we argue that the inclusion of richer media types such as photos, videos, or URLs, is associated with higher customer engagement and it is expected that more media rich brand page will show stronger relation with the antecedents of customer engagement.

Studying the moderating effects of media richness on the relationships between the independent and dependant variables will be of theoretical interest [45] [46]. In customer relationships, moderation takes place when the variable $M$ (moderating variable) modifies the relationship between the variables $\mathrm{X}$ (independent variable) and Y (dependent variable) [47] by either increasing or decreasing the strength of the relationship. For the purposes of this study, media richness was manipulated at two levels: less and morerich. Based on the above discussion, three further hypotheses can thus be formulated.

H4: Media richness will strengthen the positive relationship between information quality of the brand page and customer engagement with the brand page.

H5: Media richness will strengthen the positive relationship between interaction quality of the brand page and customer engagement with the brand page.

H6: Media richness will strengthen the positive relationship between self-expressive behaviour elicited on the brand page and customer engagement with the brand page.

All the hypotheses discussed above are visually presented in Figure 1.

Data for the analysis was collected using a questionnaire survey. Most of the scales used to measure the constructs in this study are adapted from previous studies in order to ensure content validity. Items measuring customer engagement-vigour, dedication, and absorption were adopted from Cheung et al., [18]. The self-expressive behaviour was measured using a scale developed by Higie and Feick (1989). To study interpersonal interaction and information quality, items from previous studies were adopted [48]. Media richness was measured by using consumer perception about the richness of the brand page in terms of inclusion of media types such as audio-visuals, photos and other links. 


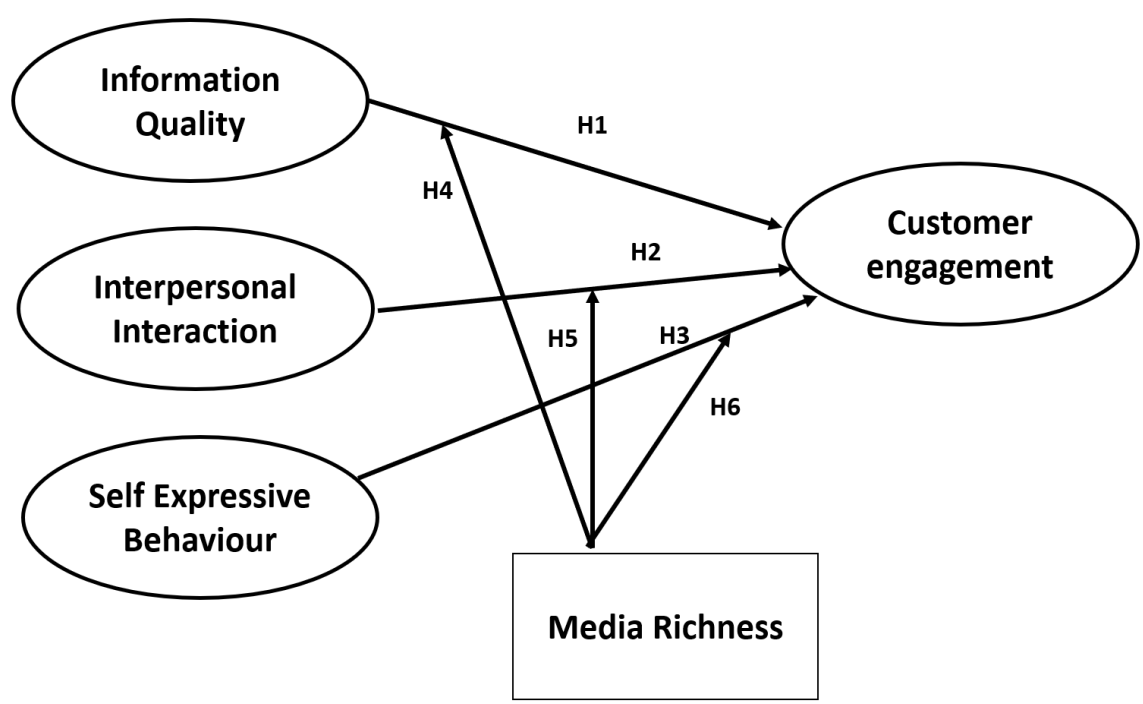

Figure 1. Conceptual model.

The survey was conducted in three stages for the present study: qualitative field interviews followed by a pilot study and the final study through a questionnaire. 20 exploratory interviews were conducted (8 academicians, 4 industry experts and 8 end consumers) with the intent to clarify the constructs and structure of the study framework. The academicians were selected on the basis of their expertise in the areas of digital marketing and word of mouth marketing. The industry experts were practitioners who were handling roles pertaining to digital marketing. The experts were drawn from the acquaintance pool of the authors. The end-consumer respondents were selected using convenience sampling. The interviews lasted between $40-60$ minutes. This step was necessary for development of the instrument. The instrument was then checked for its face validity and content validity issues with the help of academic and industry experts. Later, a pilot study was conducted using the instrument with a sample of 154 respondents. The objective of the pilot study was to test the reliability of the scales used to measure different constructs in the instrument. After examining the results from these preliminary respondents, the questionnaire was finally distributed amongst the final sample for the research among students/executives/alumni of an urban university. The sample was diverse with respect to key demographics including computer knowledge. Each item was measured using a six-point Likert agreement scale (with 6 denoting strongly agree and 1 denoting strongly disagree)

Nearly 1500 respondents were contacted and administered a screening questionnaire ascertaining whether they were active on social media and were exposed to brand pages on social media. Around 955 respondents were found eligible and the final questionnaire was distributed amongst them. Only $667 \mathrm{com}$ pletely filled questionnaires were returned. However final usable sample after the removal of suspicious pattern data, outliers etc. was 479 . There were 23 items in the model and thus the sample size of requirements of both 5:1 [49] and 10:1 
[50] were met. Table 1 provides certain descriptive statistics of the sample. Nearly $60 \%$ of the respondents were males while $40 \%$ were females. A large majority of the respondents were in the age group of 20 - 30 years and a significant majority of respondents (46.56\%) had encountered brand pages on Facebook.

\section{Analysis and Results}

We used covariance-based (CB) SEM (AMOS). First, a psychometric assessment of the measurement model was conducted. Thereafter, the structural model was evaluated. This sequence of analysis provides confidence that the structural relationships being evaluated are reflected in the measurements deployed and have desired psychometric properties [51].

\subsection{Measurement Model}

Customer engagement emerged as a second-order construct. In the Confirmatory Factor Analysis (CFA), customer engagement emerged as a three-factor second-order reflective construct. The second order was considered as the CFA showed high correlations between the four constructs. The results clearly support that customer engagement is explained through the three dimensions viz., vigour, dedication, and absorption. The fit indices $\left(\chi^{2} / \mathrm{df}=3.65\right.$, GFI $=0.89$, RMSEA $=0.074, \mathrm{NFI}=0.884, \mathrm{CFI}=0.82)$ suggest that the model with the three latent variables represents a good fit to the data. Thus, customer engagement was a holistic construct encompassing the four sub-constructs. The other three constructs were first-order reflective constructs.

\subsection{Reliability and Validity of Constructs}

Test of convergent validity was conducted to assess the extent to which the scale

Table 1. Descriptive statistics of the sample.

\begin{tabular}{ccc}
\hline & Category & Number of Users (Percentage) \\
\hline Gender & Female & $193(40.29 \%)$ \\
Male & $<20$ & $286(59.71 \%)$ \\
& $21-25$ & $15(3.13 \%)$ \\
& $26-30$ & $281(58.66 \%)$ \\
Social Media Platform chosen & $30>$ & $170(35.49 \%)$ \\
& Facebook & $13(2.71 \%)$ \\
Google Plus & LinkedIn & $223(46.56 \%)$ \\
More rich media & Twitter & $52(11.90 \%)$ \\
Less rich media & Number of Brand pages (12) & $147(30.69 \%)$ \\
& Number of brand pages (11) & 234 \\
\hline
\end{tabular}


items were theoretically related. Convergent validity assessment involved three criteria, 1) at least 0.70 composite reliability, 2) at least 0.50 average variance extracted [52], and 3) greater than 0.50 item loadings on their expected factor and less than 0.40 on other factors [53].

Table 2 shows that all convergent validity criteria were met, i.e., $\mathrm{CR}$ values ranged from 0.79 to 0.87 , average variance extracted values ranged from 0.52 to 0.57 , and item loadings were higher than 0.60 .

Table 2. AVE, CR and other statistics.

\begin{tabular}{|c|c|c|c|c|c|c|c|c|}
\hline & & & $\begin{array}{l}\text { Standardised } \\
\text { Estimates }\end{array}$ & S.E. & C.R. & $\mathrm{P}$ & AVE & CR \\
\hline Information quality & & & & & & & 0.56 & 0.79 \\
\hline I find the information in the page to be valuable & IQ1 & INFOQ & 0.73 & & & & & \\
\hline I think this page is a valuable source of information & IQ2 & INFOQ & 0.87 & 0.09 & 9.92 & 0.001 & & \\
\hline There is unique information value on this page & IQ3 & INFOQ & 0.62 & 0.09 & 9.90 & 0.001 & & \\
\hline Interpersonal interaction & & & & & & & 0.52 & 0.81 \\
\hline Other members are very responsive to my post & INTP1 & INTP & 0.84 & & & & & \\
\hline On the brand page I can help others & INTP2 & INTP & 0.68 & 0.08 & 13.01 & 0.001 & & \\
\hline On this brand page I can share my ideas with other users & INTP3 & INTP & 0.60 & 0.08 & 11.88 & 0.001 & & \\
\hline On the brand page I am able to interact with like mind people & INTP4 & INTP & 0.73 & 0.08 & 13.45 & 0.001 & & \\
\hline Self-Expressive Behaviour & & & & & & & 0.53 & 0.87 \\
\hline Portrays an image of me to others & SIC1 & SELF & 0.87 & & & & & \\
\hline Part of my self-image & SIC2 & SELF & 0.67 & 0.10 & 11.70 & 0.001 & & \\
\hline Tells others about me & SIC3 & SELF & 0.61 & 0.10 & 11.12 & 0.001 & & \\
\hline Others use to judge me & SIC4 & SELF & 0.75 & 0.09 & 10.28 & 0.001 & & \\
\hline Form of self-expression & SIC5 & SELF & 0.72 & 0.13 & 12.26 & 0.001 & & \\
\hline Creates a certain image & SIC6 & SELF & 0.71 & 0.09 & 9.85 & 0.001 & & \\
\hline Dedication & & & & & & & 0.52 & 0.81 \\
\hline I am enthusiastic about the brand & DED1 & DED & 0.71 & & & 0.001 & & \\
\hline the brand inspires me & DED2 & DED & 0.62 & 0.07 & 12.16 & 0.001 & & \\
\hline I found the brand full of meaning and purpose & DED3 & DED & 0.82 & 0.08 & 11.48 & 0.001 & & \\
\hline I am interested in the brand & DED4 & DED & 0.71 & 0.07 & 12.06 & 0.001 & & \\
\hline Absorption & & & & & & & 0.53 & 0.82 \\
\hline Time flies when I am on the brand page & ABS1 & ABS & 0.70 & & & & & \\
\hline $\begin{array}{l}\text { The brand page was so absorbing that } \\
\text { I forgot about everything else }\end{array}$ & ABS2 & ABS & 0.79 & 0.12 & 5.75 & 0.001 & & \\
\hline I am rarely distracted when I am on the brand page & ABS3 & ABS & 0.68 & 0.13 & 6.71 & 0.001 & & \\
\hline Vigour & & & & & & & 0.57 & 0.80 \\
\hline I can continue on the brand page for very long periods at a time & VIG1 & VIG & 0.87 & & & 0.001 & & \\
\hline I feel vigorous when on the brand page & VIG2 & VIG & 0.72 & 0.10 & 9.15 & 0.001 & & \\
\hline I devote a lot of energy to the brand & VIG3 & VIG & 0.67 & 0.11 & 9.15 & 0.001 & & \\
\hline
\end{tabular}




\subsection{Structural Model}

For the SEM model, we used AMOS20 to test whether the empirical data conformed to the proposed model. The model included 23 items describing 6 latent constructs: interpersonal interaction, information quality, self-expressive behaviour, customer engagement and its three dimensions, viz., vigour, dedication, and absorption. We examined the model fit of our research model, as shown in Table 3. The criteria used in the SEM were as suggested by Hair et al. [51]. Although the value of GFI (0.87) was slightly less than the recommended value (0.90), all other fit indices were acceptable. Thus, the results indicated adequate model fit between our research model and the empirical data.

To test the significance of each hypothesized path in the research model, AMOS reports raw and standardized estimates for all specified paths, as well as standard errors and test statistics for each path. The result of the structural equation model is shown in Figure 2. All the relationships were supported in the model. $71 \%$ variance in customer engagement was explained by the model. The results indicate that information quality has a significant positive relationship with customer engagement. Interpersonal interaction has a significant and positive relationship with customer engagement and self-expressive behaviour also has a positive relationship with customer engagement.

\subsection{Moderation Effects}

Media richness was then included as part of the model to test for moderation. The sample was split into two to compare the coefficients of each pair respectively. The significance of the moderating effects was found by calculating T-value for cross-multiple of the moderator and dependent variables [54] [55]. Table 4 has results for the comparison of path coefficients. The path coefficients from interpersonal interaction and self-expressive behaviour to customer engagement are significantly higher for more rich media brand pages as compared

Table 3. Results of hypotheses test and fit indices.

(a)

\begin{tabular}{cccccccc}
\hline & & Estimate & S.E. & C.R & P & Label \\
\hline H1 & Customer engagement & $\begin{array}{c}\text { Information } \\
\text { quality }\end{array}$ & 0.193 & 0.038 & 5.094 & 0.001 & $\mathrm{~S}^{*}$ \\
H2 Customer engagement & $\begin{array}{c}\text { Interpersonal } \\
\text { interaction }\end{array}$ & 0.224 & 0.039 & 5.736 & 0.001 & $\mathrm{~S}$ \\
$\mathrm{H} 3$ & Customer engagement & $\begin{array}{c}\text { Self-expressive } \\
\text { behaviour }\end{array}$ & 0.774 & 0.093 & 8.354 & 0.001 & $\mathrm{~S}$ \\
\hline
\end{tabular}

${ }^{*}$-Supported, NS-Not Supported.

(b)

\begin{tabular}{ccccccc}
\hline Fit indices & $\chi^{2} / \mathrm{df}$ & RMSEA & GFI & AGFI & CFI & NFI \\
\hline Recommended value & $<3$ & $<0.08$ & $>0.90$ & $>0.80$ & $>0.90$ & $>0.90$ \\
Value in this study & 2.73 & 0.065 & 0.87 & 0.81 & 0.91 & 0.92 \\
\hline
\end{tabular}


Table 4. Results of moderating effects.

\begin{tabular}{|c|c|c|c|c|c|c|c|c|c|}
\hline & & \multicolumn{3}{|c|}{ More rich media } & \multicolumn{3}{|c|}{ Less rich media } & \multirow[b]{2}{*}{$\begin{array}{c}\text { CR for } \\
\text { comparison }(t)\end{array}$} & \multirow[b]{2}{*}{ Hypothesis } \\
\hline & & Estimate & S.E. & C.R. & Estimate & S.E. & C.R. & & \\
\hline $\begin{array}{c}\text { customer } \\
\text { engagement }\end{array}$ & $\begin{array}{c}\text { Interpersonal } \\
\text { interaction }\end{array}$ & 0.226 & 0.077 & $2.93^{* *}$ & 0.015 & 0.041 & 0.362 & 2.413 & $S$ \\
\hline $\begin{array}{l}\text { customer } \\
\text { engagement }\end{array}$ & $\begin{array}{l}\text { Information } \\
\text { quality }\end{array}$ & 2.386 & 0.185 & $12.89^{* *}$ & 3.029 & 0.284 & $10.67^{\star *}$ & 1.896 & NS \\
\hline $\begin{array}{l}\text { customer } \\
\text { engagement }\end{array}$ & $\begin{array}{c}\text { self-expressive } \\
\text { behaviour }\end{array}$ & 2.443 & 0.191 & $12.82^{* *}$ & 1.461 & 0.325 & $4.49^{* *}$ & 2.01 & $S$ \\
\hline
\end{tabular}

${ }^{* *}$ for $\mathrm{p} \leq 0.01$ and ${ }^{*}$ for $\mathrm{p} \leq 0.05$; S: Supported, PS: Partially Supported, NS: Not Supported.

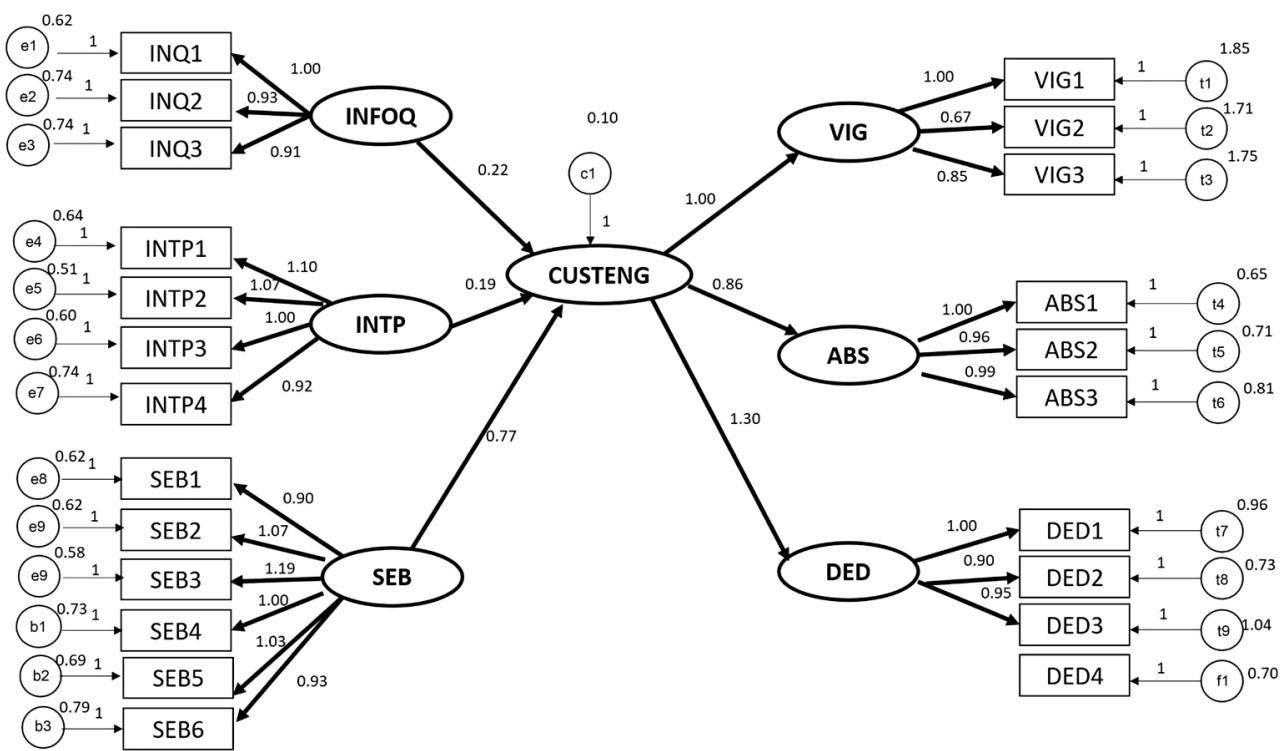

Figure 2. Structural equation model.

to less rich media. However, media richness showed no impact on the relationship between information quality and customer engagement. This indicated that if the brand page is less media rich then interaction quality has insignificant impact on customer engagement. Thus, more media rich brand pages are important to engage customers. Firms need to create media rich interface to engage customers. Similarly, customers exhibiting self-expressive behaviour are more inclined to brand pages that are media rich.

\section{Discussion}

The extant empirical studies on brand engagement have analysed customer engagement as an outcome of one of different variables, such as, organizational offerings or activities [10], a brand [8] [11] [15] [56], the brand community members [13] [19] [25] [57]. This is consistent with other empirical work in the area of brand engagement [5] [58].

This study demonstrates that customer engagement is not embedded in just a 
linear consumer-brand continuum. Customer engagement resides in a network of dynamic and complex interactions which include the customer himself, other individuals, the brand and the firm. These findings reinforce customer engagement as being a multi-dimensional construct. Hence, the findings are in line with previous research by Brodie, Hollebeek, Juric, et al. [5] and Hollebeek et al. [15]. The findings also revalidate the three-dimension framework of customer engagement proposed by Cheung et al. [18].

The study findings also bring to light the importance of media rich brand pages demonstrating that media rich brand pages are more likely to have higher brand engagement with customers, thus, highlighting the need for innovative and engaging brand page interface.

The study findings are in line with customer engagement framework proposed by Wirtz et al. [59] on precursors of brand community engagement as being brand related, and of social and functional character. High brand community engagement leads to benefits to the community and the brand itself, more so in positively impacting community participation and behaviours [60].

\section{Conclusions}

The intent of this study was to offer a refinement of the concept of customer engagement with online brand pages. As discussed earlier, despite the abundant literature in the area of customer engagement [8] [59] [61], there is a lacuna of studies when it comes to exploring customer engagement in the context of social media brand pages. The study, therefore, contributes to the extant literation on customer engagement in two ways. First, it explores in depth the dimensionality of customer engagement in the context of social media brand pages. This area so far has received little empirical attention. Second, the study furthers our understanding on the role of media richness and its relationship with customer engagement and its antecedents. The latter findings are interesting since media rich brand pages seem to foster greater customer engagement. Brands could consider having an index for media richness and vary this based on the objectives for the brand. There is an obvious trade-off here since media rich content while being more effective in increasing engagement is also likely to be more expensive. Brands can thus take a conscious decision on the level of media richness required on their page.

The study has some limitations. The design of the study does not factor in the differences across social media platforms. It would be interesting to do a comparative analysis of such platform in terms of impact of the antecedents to customer engagement. Another interesting area of exploration would be the differences in engagement for different categories of brands. We do not find many empirical insights on how the brand categories themselves impact customer engagement.

\section{Conflicts of Interest}

The authors declare no conflicts of interest regarding the publication of this paper. 


\section{References}

[1] Chaffey, D. (2019) Global Social Media Research Summary 2019. Smart Insights.

[2] Chaturvedi, A. (2017) India Inc Sets Up Social Media HQs to Cosy Up to the Millenials. The Economic Times, 5.

[3] Euromonitor Digital Landscape in India (2019).

[4] Hollebeek, L.D., et al. (2016) Epilogue to the Special Issue and Reflections on the Future of Engagement Research. Journal of Marketing Management, 32, 586-594. https://doi.org/10.1080/0267257X.2016.1144340

[5] Brodie, R.J., Hollebeek, L.D., Juric, B. and Ilic, A. (2011) Customer Engagement: Conceptual Domain, Fundamental Propositions, and Implications for Research. Journal of Service Research, 14, 252-271. https://doi.org/10.1177/1094670511411703

[6] Brodie, R.J., Ilic, A., Juric, B. and Hollebeek, L. (2013) Consumer Engagement in a Virtual Brand Community: An Exploratory Analysis. Journal of Business Research, 66, 105-114. https://doi.org/10.1016/j.jbusres.2011.07.029

[7] Bowden, J. (2009) The Process of Customer Engagement: A Conceptual Framework. Journal of Marketing Theory and Practice, 17, 63-74. https://doi.org/10.2753/MTP1069-6679170105

[8] Hollebeek, L.D. (2011) Exploring Customer Brand Engagement: Definition and Themes. Journal of Strategic Marketing, 19, 555-573. https://doi.org/10.1080/0965254X.2011.599493

[9] Mollen, A. and Wilson, H. (2010) Engagement, Telepresence and Interactivity in Online Consumer Experience: Reconciling Scholastic and Managerial Perspectives. Journal of Business Research, 63, 919-925. https://doi.org/10.1016/j.jbusres.2009.05.014

[10] Vivek, S.D., Beatty, S.E. and Morgan, R.M. (2012) Customer Engagement: Exploring Customer Relationships beyond Purchase. Journal of Marketing Theory and Practice, 20, 122-146. https://doi.org/10.2753/MTP1069-6679200201

[11] Sprott, D., Czellar, S. and Spangenberg, E. (2009) The Importance of a General Measure of Brand Engagement on Market Behavior: Development and Validation of a Scale. Journal of Marketing Research, 46, 92-104. https://doi.org/10.1509/jmkr.46.1.92

[12] Patterson, P.G., Yu, T. and De Ruyter, K. (2006) Understanding Customer Engagement in Services. In: Advancing Theory, Maintaining Relevance, Proceedings of ANZMAC2006 Conference, Brisbane, 4-6.

[13] Algesheimer, R., Borle, S., Dholakia, U.M. and Singh, S.S. (2010) The Impact of Customer Community Participation on Customer Behaviors: An Empirical Investigation. Marketing Science, 29, 756-769. https://doi.org/10.1287/mksc.1090.0555

[14] Calder, B.J., Malthouse, E.C. and Schaedel, U. (2009) An Experimental Study of the Relationship between Online Engagement and Advertising Effectiveness. Journal of Interactive Marketing, 23, 321-331. https://doi.org/10.1016/j.intmar.2009.07.002

[15] Hollebeek, L.D., Glynn, M.S. and Brodie, R.J. (2014) Consumer Brand Engagement in Social Media: Conceptualization, Scale Development and Validation. Journal of Interactive Marketing, 28, 149-165. https://doi.org/10.1016/j.intmar.2013.12.002

[16] Baldus, B.J., Voorhees, C. and Calantone, R. (2015) Online Brand Community Engagement: Scale Development and Validation. Journal of Business Research, 68 , 978-985. https://doi.org/10.1016/j.jbusres.2014.09.035

[17] Chan, T.K.H., Cheung, C.M.K., Zheng, X., Lee, M.K.O. and Lee, Z.W.Y. (2014) An- 
tecedents and Consequences of Customer Engagement in Online Brand Communities. Journal of Marketing Analytics, 2, 81-97. https://doi.org/10.1057/jma.2014.9

[18] Cheung, C.M.K., Lee, M.K.O. and Jin, X.L. (2011) Customer Engagement in an Online Social Platform: A Conceptual Model and Scale Development. 2011 International Conference on Information Systems, Shanghai, China, 4-7 December 2011.

[19] Laroche, M., Habibi, M.R., Richard, M.O. and Sankaranarayanan, R. (2012) The Effects of Social Media Based Brand Communities on Brand Community Markers, Value Creation Practices, Brand Trust and Brand Loyalty. Computers in Human Behavior, 28, 1755-1767. https://doi.org/10.1016/j.chb.2012.04.016

[20] Brodie, R.J., Ilic, A., Juric, B. and Hollebeek, L. (2013) Consumer Engagement in a Virtual Brand Community: An Exploratory Analysis. Journal of Business Research, 66, 105-114. https://doi.org/10.1016/j.jbusres.2011.07.029

[21] Hollebeek, L.D. (2011) Demystifying Customer Brand Engagement: Exploring the Loyalty Nexus. Journal of Marketing Management, 27, 785-807. https://doi.org/10.1080/0267257X.2010.500132

[22] Gambetti, R.C., Graffigna, G. and Biraghi, S. (2012) The Grounded Theory Approach to Consumer-Brand Engagement. International Journal of Market Research, 54, 659-687. https://doi.org/10.2501/IJMR-54-5-659-687

[23] So, K.K.F., King, C. and Sparks, B. (2014) Customer Engagement with Tourism Brands: Scale Development and Validation. Journal of Hospitality \& Tourism Research, 38, 304-329. https://doi.org/10.1177/1096348012451456

[24] van Doorn, J., et al. (2010) Customer Engagement Behavior: Theoretical Foundations and Research Directions. Journal of Service Research, 13, 253-266. https://doi.org/10.1177/1094670510375599

[25] Gummerus, J., Liljander, V., Weman, E. and Pihlström, M. (2012) Customer Engagement in a Facebook Brand Community. Management Research Review, 35, 857-877. https://doi.org/10.1108/01409171211256578

[26] Newman, D.A. and Harrison, D.A. (2008) Been There, Bottled That: Are State and Behavioral Work Engagement New and Useful Construct 'Wines'? Industrial and Organizational Psychology, 1, 31-35. https://doi.org/10.1111/j.1754-9434.2007.00003.x

[27] Wu, L. (2013) Social Network Effects on Performance and Layoffs: Evidence from the Adoption of a Social Networking Tool. Information Systems Research, 24, 30-51. https://doi.org/10.1287/isre.1120.0465

[28] Dholakia, U.M., Bagozzi, R.P. and Pearo, L.K. (2004) A Social Influence Model of Consumer Participation in Network- and Small-Group-Based Virtual Communities. International Journal of Research in Marketing, 21, 241-263. https://doi.org/10.1016/j.ijresmar.2003.12.004

[29] Al-Debei, M.M., Al-Lozi, E. and Papazafeiropoulou, A. (2013) Why People Keep Coming Back to Facebook: Explaining and Predicting Continuance Participation from an Extended Theory of Planned Behaviour Perspective. Decision Support Systems, 55, 43-54. https://doi.org/10.1016/j.dss.2012.12.032

[30] Liang, T.P., Ho, Y.T., Li, Y.W. and Turban, E. (2011) What Drives Social Commerce: The Role of Social Support and Relationship Quality. International Journal of Electronic Commerce, 16, 69-90. https://doi.org/10.2753/JEC1086-4415160204

[31] Gabriel, Y. and Lang, T. (1995) The Unmanageble Consumer: Contemporary Consumption and Its Fragmentations. Sage Publications Inc., London.

[32] Tyler, L.E. (1978) Individuality: Human Possibilities and Personal Choice in the 
Psychological Development of Men and Women. Jossey-Bass Inc., New York.

[33] Thompson, J.B. (1995) The Media and Modernity: A Social Theory of the Media. Polity Press, Cambridge.

[34] Nurmi, J.E. (2013) Socialization and Self-Development: Channeling, Selection, Adjustment, and Reflection. In: Lerner R.M. and Steinberg, L., Eds., Handbook of Adolescent Psychology, 2nd Edition, John Wiley \& Sons, Inc., New York, 85-124. https://doi.org/10.1002/9780471726746.ch4

[35] Castells, M. (2010) Communication Power: Mass Communication, Mass self-Communication, and Power Relationships in the Network Society. In: Curran, J. and Hesmondhalgh, D., Eds., Media and Society, 6th Edition, Bloomsbury Academic, London.

[36] Sirgy, M.J. (1982) Self-Concept in Consumer Behavior: A Critical Review. Journal of Consumer Research, 9, 287-300. https://doi.org/10.1086/208924

[37] Jamal, A. and Al-Marri, M. (2007) Exploring the Effect of Self-Image Congruence and Brand Preference on Satisfaction: The Role of Expertise. Journal of Marketing Management, 23, 613-629. https://doi.org/10.1362/026725707X2266

[38] Ericksen, M.K. (1997) Using Self-Congruity and Ideal Congruity to Predict Purchase Intention: A European Perspective. Journal of Euromarketing, 6, 41-56. https://doi.org/10.1300/J037v06n01_04

[39] Graeff, T.R. (1996) Using Promotional Messages to Manage the Effects of Brand and Self-Image on Brand Evaluations. Journal of Consumer Marketing, 13, 4-17. https://doi.org/10.1108/07363769610118921

[40] Belk, R.W. (1988) Possessions and the Extended Self. Journal of Consumer Research, 15, 139-168. https://doi.org/10.1086/209154

[41] Kleine, S.S., Kleine, R.E. and Allen, C.T. (1995) How Is a Possession 'Me' or 'Not Me'? Characterizing Types and an Antecedent of Material Possession Attachment. Journal of Consumer Research, 22, 327-343. https://doi.org/10.1086/209454

[42] Phau, I. and Lau, K.C. (2001) Brand Personality and Consumer Self-Expression: Single or Dual Carriageway? Journal of Brand Management, 8, 428-444.

https://doi.org/10.1057/palgrave.bm.2540042

[43] Goffman, E. (1959) The Presentation of Self In Everyday Life.

[44] Daft, R.L. and Lengel, R.H. (1986) Organizational Information Requirements, Media Richness and Structural Design. Management Science, 32, 554-571.

https://doi.org/10.1287/mnsc.32.5.554

[45] Dabholkar, P.A. and Bagozzi, R.P. (2002) An Attitudinal Model of Technology-Based Self-Service: Moderating Effects of Consumer Traits and Situational Factors. Journal of the Academy of Marketing Science, 30, 184-201. https://doi.org/10.1177/00970302030003001

[46] Nysveen, H. and Pedersen, P.E. (2005) Explaining Intention to Use Mobile Chat Services: Moderating Effects of Gender. Journal of Consumer Marketing, 22, 247-256. https://doi.org/10.1108/07363760510611671

[47] Baron, R.M. and Kenny, D.A. (1986) The Moderator-Mediator Variable Distinction in Social The Moderator-Mediator Variable Distinction in Social Psychological Research: Conceptual, Strategic, and Statistical Considerations. Journal of Personality and Social Psychology, 51, 1173-1182. https://doi.org/10.1037//0022-3514.51.6.1173

[48] Chow, W.S. and Shi, S. (2015) Investigating Customers' Satisfaction with Brand Pages in Social Networking Sites. Journal of Computer Information Systems, 55, 48-58. https://doi.org/10.1080/08874417.2015.11645756 
[49] Bentler, P.M. and Chou, C.P. (1987) Practical Issues in Structural Modeling. Sociological Methods \& Research, 16, 78-117. https://doi.org/10.1177/0049124187016001004

[50] Baumgartner, H. and Homburg, C. (1996) Applications of Structural Equation Modeling in Marketing and Consumer Research: A Review. International Journal of Research in Marketing, 13, 139-161. https://doi.org/10.1016/0167-8116(95)00038-0

[51] Hair, J.F., Anderson, R.E., Tatham, R.L. and Black, W.C. (1998) Multivariate Data Analysis with Readings. 5nd Edition, Pearson, London.

[52] Larcker, D.F. and Fornell, C. (1981) Evaluating Structural Equation Models with Unobservable Variables and Measurement Error. Journal of Marketing Research, 18, 39-50. https://doi.org/10.2307/3151312

[53] Cheung, W., Chang, M.K. and Lai, V.S. (2000) Prediction of Internet and World Wide Web Usage at Work: A Test of an Extended Triandis Model. Decision Support Systems, 30, 83-100. https://doi.org/10.1016/S0167-9236(00)00125-1

[54] Chin, W.W. (1998) The Partial Least Squares Approach to Structural Equation Modeling. In: Marcouluides, G.A., Ed., Modern Methods for Business Research, Eribaum Associates, Inc., Lawrence, NJ, 295-336.

[55] Chin, W.W., Marcelin, B.L. and Newsted, P.R. (2003) A Partial Least Squares Latent Variable Modeling Approach for Measuring Interaction Effects: Results from a Monte Carlo Simulation Study and an Electronic-Mail Emotion/Adoption Study. Information Systems Research, 14, 189-217. https://doi.org/10.1287/isre.14.2.189.16018

[56] Jaakkola, E. and Alexander, M. (2014) The Role of Consumer Engagement in Value Co-Creation: A Service System Perspective. Journal of Service Research, 17, 247-261. https://doi.org/10.1177/1094670514529187

[57] Kuo, Y.F. and Feng, L.H. (2013) Relationships among Community Interaction Characteristics, Perceived Benefits, Community Commitment, and Oppositional Brand Loyalty in Online Brand Communities. International Journal of Information Management, 33, 948-962. https://doi.org/10.1016/j.ijinfomgt.2013.08.005

[58] Vivek, S.D., Beatty, S.E., Dalela, V. and Morgan, R.M. (2014) A Generalized Multidimensional Scale for Measuring Customer Engagement. Journal of Marketing Theory and Practice, 22, 401-420. https://doi.org/10.2753/MTP1069-6679220404

[59] Wirtz, J., et al. (2013) Managing Brands and Customer Engagement in Online Brand Communities. Journal of Service Management, 24, 223-244. https://doi.org/10.1108/09564231311326978

[60] Algesheimer, R., Dholakia, U.M. and Herrmann, A. (2005) The Social Influence of Brand Community: Evidence from European Car Clubs. Journal of Marketing, 69, 19-34. https://doi.org/10.1509/jmkg.69.3.19.66363

[61] Hollebeek, L.D. and Chen, T. (2014) Exploring Positively- versus Negatively-Valenced Brand Engagement: A Conceptual Model. Journal of Product \& Brand Management, 23, 62-74. https://doi.org/10.1108/JPBM-06-2013-0332 